\title{
Reference Result Target Anatomic Site Code
}

National Cancer Institute

\section{Source}

National Cancer Institute. Reference Result Target Anatomic Site Code. NCI Thesaurus.

Code C94039.

A coded value specifying the anatomic location that is the focus of a reference result. 